\title{
Time using a computer as a discriminator of obesity, sedentarism and cardiovascular risk factors in university students
}

\author{
Tempo utilizando computador como discriminador de obesidade, sedentarismo e fatores de risco cardiovascular \\ em universitários
}

\author{
Heloísa Silva Guerra1,2 (D) heloisasguerra@gmail.com \\ Adriana Vieira Macedo Brugnoli, (1) adrianavieiramacedo@hotmail.com \\ Raiana Rodrigues Costa Melo1,2 (D) raianarodrigues@unirv.edu.br \\ Emílio Hideyuki Moriguchi' (D) emilio.moriguchi@gmail.com \\ Marcos Pascoal Pattussi' (D) mppattussi@unisinos.br \\ Juvenal Soares Dias da Costa ${ }^{1,3}$ (D) episoares@terra.com.br
}

\begin{abstract}
Introduction: University students are at greater risk of adopting a sedentary behavior due to their routine, with a large amount of time being dedicated to classes and studying in front of a computer. This situation has become a matter of concern, because sedentary behavior has been associated with adverse health outcomes such as mortality and chronic non-communicable diseases.

Objective: To analyze the time spent using the computer as a discriminator of obesity, sedentary lifestyle and cardiovascular risk factors in University students.

Method: This was a cross-sectional study with 2,275 students from courses in the health area of a public institution in Goiás. Data were obtained by applying a questionnaire consisting of sociodemographic, course-related, behavioral and health variables. The outcome variable was time using the computer (TC). The discriminatory power and the cutoff points of time using the computer for the outcomes of interest were identified using the Receiver Operating Characteristic (ROC) curves with $95 \% \mathrm{Cl}$.

Result: The mean time spent using the computer for studying, working, or leisure was 3.90 hours/day for women and 3.82 hours/day for men. The area under the ROC curve between TC and sedentary lifestyle was $0.54(95 \% \mathrm{Cl} 0.51-0.58)$ for women and $0.56(95 \% \mathrm{Cl} 0.50-0.63)$ for men. As for systemic arterial hypertension $(\mathrm{SAH})$ it was $0.57(95 \% \mathrm{Cl} 0.50-0.64)$ for women. The best cutoff points related to these conditions were 3.5 and 4.5 hours, respectively.
\end{abstract}

Conclusion: The TC showed good predictive capacity to discriminate a sedentary lifestyle and SAH among University students. It is suggested that the reduction of TC and its replacement by active activities can contribute to improving the health profile and quality of life of students.

Keywords: Sedentary Behavior; Lifestyle; Student Health.

\section{RESUMO}

Introdução: Os universitários apresentam maior risco de adotar o comportamento sedentário em virtude da própria rotina, a qual requer muito tempo dedicado às aulas e a utilização frequente do computador para os estudos. Essa situação tem se tornado preocupante porque o comportamento sedentário tem sido associado a desfechos adversos em saúde, como mortalidade e doenças crônicas não transmissíveis.

Objetivo: Este estudo teve como objetivo analisar o tempo despendido com o uso do computador como discriminador da obesidade, do sedentarismo e de fatores de risco cardiovascular em universitários.

Método: Trata-se de estudo transversal realizado com 2.275 acadêmicos de cursos da área da saúde de uma fundação pública do estado de Goiás. Os dados foram obtidos por meio da aplicação de um questionário composto por variáveis sociodemográficas, relativas ao curso e a aspectos comportamentais e de saúde. A variável de desfecho foi o tempo utilizando o computador (TC). Identificaram-se o poder discriminatório e os pontos de corte do TC para os desfechos de interesse por meio das curvas Receiver Operating Characteristic (ROC) com IC95\%.

Resultado: O tempo médio usando o computador para estudos, trabalho ou lazer foi de 3,90 horas/dia para mulheres e 3,82 horas/dia para homens. A área sob a curva ROC entre o TC e o sedentarismo foi de 0,54 (IC95\% 0,51-0,58) para mulheres e 0,56 (IC95\% 0,50-0,63) para homens. Já para a hipertensão arterial sistêmica (HAS), foi de 0,57 (IC95\% 0,50-0,64) para mulheres. Os melhores pontos de corte relacionados a essas condições foram 3,5 e 4,5 horas, respectivamente.

Conclusão: O TC apresentou boa capacidade preditiva para discriminar o sedentarismo e a HAS entre universitários. Sugere-se que a diminuição do TC e sua substituição por atividades ativas possam contribuir para a melhoria do perfil de saúde e a qualidade de vida dos acadêmicos.

Palavras-chave: Comportamento Sedentário; Estilo de Vida; Saúde do Estudante.

${ }^{1}$ Universidade do Vale do Rio dos Sinos, São Leopoldo, Rio Grande do Sul, Brazil.

2 Universidade de Rio Verde, Aparecida de Goiânia, Goiás, Brazil.

${ }^{3}$ Universidade Federal de Pelotas, Pelotas, Rio Grande do Sul, Brazil.

Chief Editor: Rosiane Viana Zuza Diniz. Associate editor: Antonio da Silva Menezes Junior.

Received on 09/10/21; Accepted on 11/04/21. | Evaluated by double blind review process. 


\section{INTRODUCTION}

Sedentary behavior (SB) has been investigated in different contexts due to its negative relationship with health. When considered excessive, it is associated with outcomes such as mortality, cardiovascular disease (CVD), type 2 diabetes and metabolic syndrome'. Long periods spent in sedentary activities are associated with increases in the risk of obesity and less time spent on physical activity ${ }^{2,3}$.

University students constitute a group at greater risk of adopting SB because of their routine, with a large amount of time spent in classes and studying in front of a computer ${ }^{4}$. Studies on SB, show great variability regarding their measurement methods, as well as different cutoff points used to classify individuals with higher or lower levels of SB and the types of behavior assessed. However, a systematic review whose objective was to summarize the evidence on SB levels in university students indicated that time of computer use showed a significantly higher prevalence in relation to other screen time modalities ${ }^{5}$.

The life changes that started with university admission has been related to a decrease in the practice of physical activity (PA) and an increase in $\mathrm{SB}^{6,7}$. Moreover, it is known that a considerable proportion of university students have higher levels of SB compared to the general adult population ${ }^{5}$.

Among the events that are harmful to health, chronic non-communicable diseases (NCDs) play a prominent role, as their occurrence has increased, constituting the group of diseases with the greatest magnitude worldwide and the main cause of death in adults, especially in low- and middleincome countries ${ }^{8}$.

The main risk factors for chronic NCDs are systemic arterial hypertension (SAH), diabetes mellitus (DM), dyslipidemia, inadequate eating habits, sedentary lifestyle, smoking and obesity ${ }^{9,10}$. Many of these factors are likely to arise or be aggravated during the undergraduate school period, because starting a university course can imply a change in lifestyle, with the adoption of unhealthy habits 9 .

Recent data from the National Health Survey showed that approximately 96 million Brazilians over 18 years of age were overweight, corresponding to $60.3 \%$ of the population. Additionally, $39.2 \%$ had SAH and $15.9 \%$ had diabetes ${ }^{11}$.

Establishing the quantitative relationship between time using the computer and certain conditions such as obesity, sedentary lifestyle and cardiovascular risk factors can contribute to the implementation of measures that discourage these behaviors and encourage university students to adopt more active practices, thus preventing the aforementioned diseases.

Therefore, the aim of this study was to analyze the time spent using the computer as a discriminator of obesity, sedentary lifestyle and cardiovascular risk factors in university students.

\section{METHODS}

A cross-sectional, school-based study was carried out in a census-type sample of university students linked to a municipal public institution located in the state of Goiás, Brazil, in 2018.

Students of both genders aged 18 years or over were included, and those who had some type of physical disability and those aged 60 years or older were excluded. To calculate the sample size, an estimated prevalence of $50 \%$ was considered, taking into account the inclusion of different health-related information and a $3 \%$ error. A total of $10 \%$ were added considering possible losses or refusals and $15 \%$ to control for confounding factors. Therefore, the need to include 953 individuals was estimated.

The study population consisted of all undergraduate students from the institution's health courses (Physical Education, Nursing, Pharmacy, Physiotherapy, Medicine and Dentistry), distributed in three campuses (Aparecida de Goiânia, Goianésia and Rio Verde), in a total of 2,658 students.

To carry out the data collection, a printed, pre-tested, standardized and self-applicable questionnaire was used, consisting of sociodemographic, course-related, behavioral and health variables.

Time using the computer (TC) was evaluated through a question about the time spent, in hours and minutes, on a normal day of the week, using the computer for working, studying or leisure. The TC in minutes were transformed into hours.

The demographic variables included gender (female; male); age (18-19 years; 20-24 years; 25-29 years; 30 years or older), self-reported skin color/ethnicity (white; brown; black; others) and marital status (with a partner; without a partner). The socioeconomic variable corresponded to the economic classification of the Brazilian Association of Research Companies (ABEP, Associação Brasileira de Empresas de Pesquisa), whose scores were organized into categories ( $A ; B ; C / D / E)$. The ABEP classification was established based on the possession and quantity of some consumer goods, the head of the family's level of education, and access to certain public services ${ }^{12}$.

The variables related to student characteristics comprised the course (Medicine; others) and semester $\left(1^{\text {st }}\right.$ to $6^{\text {th }}$; $7^{\text {th }}$ to $\left.12^{\text {th }}\right)$. The lifestyle habits considered were smoking status (non-smoker; ex-smoker; current smoker); use of illicit drugs on the last 30 days (use; non-use); alcohol consumption (use; non-use) and the practice of physical activity (PA), collected through the International Physical Activity Questionnaire (IPAQ) $^{13}$ and categorized into: Sedentary (does not perform any physical activity for at least 10 continuous minutes during 
the week); Insufficiently Active (practices physical activity for at least 10 continuous minutes per week, but not enough to be classified as active); Active (complies with the following recommendations: a) vigorous physical activity $-\geq 3$ days/ week and $\geq 20$ minutes/session; b) moderate or walking $-\geq 5$ days/week and $\geq 30$ minutes/session; c) any added activity: $\geq$ 5 days/week and $\geq 150 \mathrm{~min} /$ week) and Very Active (complies with the following recommendations: a) vigorous PA- $\geq 5$ days/ week and $\geq 30 \mathrm{~min} /$ session; b) vigorous $\mathrm{PA}-\geq 3$ days/week and $\geq 20 \mathrm{~min} /$ session + moderate and/or walking $\geq 5$ days/week and $\geq 30 \mathrm{~min} /$ session).

Finally, the health-related information comprised the Body Mass Index (BMI) and the presence of diseases that increased cardiovascular risk. BMI was calculated from the weight and height reported by the respondent and categorized according to the cutoff points recommended by the World Health Organization (WHO), with BMI up to 24.99 (adequate weight); $>25.00$ and $<29.99$ (overweight) and $\geq 30$ (obesity) $)^{14}$. The presence of diseases was considered based on the self-reported statement, with a previous diagnosis made by a physician, of the following conditions: diabetes mellitus, systemic arterial hypertension and hypercholesterolemia.

The database was structured using the EpiData 3.1 software with double entry to correct inconsistencies. Data analysis was performed using the Statistical Package for Social Sciences (SPSS) version 22.0 software. In the descriptive analysis, the mean and standard deviation or absolute and relative frequency values and measures of association for categorical variables were calculated (Chi-square test), with $p<0.05$. A stratification strategy by gender was used due to the differences observed in the literature regarding factors associated with SB between men and women, depending on the type of activity considered ${ }^{15,16}$.

The discriminatory capacity, sensitivity and specificity of time using the computer to assess the presence of established conditions were performed from the analysis of the Receiver Operating Characteristic (ROC) curves. The area under the curve (AUC) determined the discriminatory capacity of the indicator for the presence or absence of obesity, sedentary lifestyle and risk factors for cardiovascular disease. Areas with values $>0.50$ and a lower limit of the $95 \% \mathrm{Cl}>0.50$ were considered discriminatory for estimating the cutoff points ${ }^{17}$. Sensitivity and specificity levels for the cutoff points were estimated and the points that best discriminated the presence of the abovementioned conditions were the ones that showed a balance between these two characteristics ${ }^{18}$.
The Guidelines and Regulatory Norms for Research Involving Human Beings were followed, according to Resolution 466 of the Brazilian National Health Council. The Ethics Committees of the Universidade do Vale dos Sinos (Opinion $\mathrm{n}$. 2.892.764) and University de Rio Verde (Opinion n. 2.905. 704) approved the study.

\section{RESULTS}

A total of 2,275 university students participated in the study. The mean time spent using the computer for studying, working or leisure was 3.90 (SD \pm 2.98 ) hours/day for women and 3.82 (SD \pm 2.96 ) hours/day for men.

The stratified analysis showed differences between the students regarding age, skin color/ethnicity, economic class, undergraduate course, smoking status, alcohol consumption, physical activity practice, BMI and presence of hypercholesterolemia (Table 1). The study identified a higher proportion of female individuals aged 20 to 24 years (70.7\%), of white skin color/ethnicity (58\%), non-smokers $(90.3 \%)$, physically active $(42.2 \%)$, without obesity $(96.0 \%)$ and who did not have hypercholesterolemia (81.5\%). Among the male participants, there was a higher prevalence of individuals in economic class A (53.5\%), enrolled in the Medicine course (74.2\%) and reporting the consumption of alcohol (79.1\%) (Table 1) .

Based on the performed analysis, the values of the Areas Under the Curve (AUC) of time using the computer were identified as a discriminator of obesity, sedentary lifestyle and cardiovascular risk factors in university students. It was observed that TC was a good discriminator of sedentary lifestyle among women and men, and the presence of systemic arterial hypertension among women. For the other conditions, the $\mathrm{p}$-value was not statistically significant (Table 2 ).

By analyzing the cutoff points with greater accuracy and sensitivity and specificity values of the relationship between time using the computer and sedentary lifestyle, it was observed that, among women, the cutoff point that best discriminated this condition was more than 3.5 hours/day (sensitivity $=53 \%$ and specificity $=53 \%$ ) (Graph 1$)$.

Among men, the cutoff point that best discriminated the presence of sedentary lifestyle was also $\geq 3.5$ hours/day (sensitivity $=57 \%$ and specificity $=55 \%$ ) (Graph 2).

Graph 3 shows the area under the ROC curve between time using the computer and the presence of $\mathrm{SAH}$ in females, and the best cutoff point found was $\geq 4.5$ hours/day (sensitivity $=45 \%$ and specificity $=66 \%$ ). 
Table 1. Sociodemographic characteristics, students, life habits and health of university students. Goiás, 2018.

\begin{tabular}{|c|c|c|c|c|c|}
\hline \multirow{2}{*}{ Variable } & \multicolumn{2}{|c|}{ Female } & \multicolumn{2}{|c|}{ Male } & \multirow{2}{*}{ p-value } \\
\hline & $\mathbf{N}$ & $\%$ & $\mathbf{N}$ & $\%$ & \\
\hline Age group $(n=2.275)$ & & & & & $0.035^{*}$ \\
\hline 20 to 24 years old & 1120 & 70.7 & 462 & 66.9 & \\
\hline 25 to 29 years old & 194 & 12.2 & 96 & 13.9 & \\
\hline Skin color /ethnicity $(n=2.275)$ & & & & & $0.050^{*}$ \\
\hline White & 918 & 58.0 & 386 & 55.9 & \\
\hline Black & 47 & 3.0 & 37 & 5.4 & \\
\hline Brown & 545 & 34.4 & 235 & 34.0 & \\
\hline Without partner & 1396 & 88.6 & 597 & 87.4 & \\
\hline Economic class $(n=2.173)$ & & & & & $0.000^{*}$ \\
\hline A & 624 & 41.0 & 348 & 53.5 & \\
\hline B & 714 & 46.9 & 238 & 36.6 & \\
\hline$C / D / E$ & 184 & 12.1 & 65 & 10.0 & \\
\hline Health course $(n=2.260)$ & & & & & $0.018^{*}$ \\
\hline Medicine & 1093 & 69.3 & 507 & 74.2 & \\
\hline Others & 484 & 30.7 & 176 & 25.8 & \\
\hline Semester $(n=2.258)$ & & & & & 0.068 \\
\hline Current smoker & 67 & 4.3 & 101 & 15.1 & \\
\hline Alcohol consumption $(n=2,257)$ & & & & & $0.027^{*}$ \\
\hline No & 398 & 25.2 & 142 & 20.9 & \\
\hline Yes & 1179 & 74.8 & 538 & 79.1 & \\
\hline Use of illicit drugs $(n=2,174)$ & & & & & 0.525 \\
\hline No & 1276 & 84.3 & 550 & 83.2 & \\
\hline Yes & 237 & 15.7 & 111 & 16.8 & \\
\hline Physical activity practice $(n=2,191)$ & & & & & $0.000^{*}$ \\
\hline Very active & 291 & 19.1 & 212 & 31.9 & \\
\hline Active & 644 & 42.2 & 279 & 42.0 & \\
\hline Insufficiently active & 250 & 16.4 & 69 & 10.4 & \\
\hline Sedentary & 341 & 22.3 & 105 & 15.8 & \\
\hline Obesity $(n=2225)$ & & & & & $0.000^{*}$ \\
\hline No & 1487 & 96.0 & 599 & 88.6 & \\
\hline Yes & 62 & 4.0 & 77 & 11.4 & \\
\hline
\end{tabular}


TTable 1. (Continuation) Sociodemographic characteristics, students, life habits and health of university students. Goiás, 2018.

\begin{tabular}{|c|c|c|c|c|c|}
\hline \multirow{2}{*}{ Variable } & \multicolumn{2}{|c|}{ Female } & \multicolumn{2}{|c|}{ Male } & \multirow{2}{*}{ p-value } \\
\hline & $\mathbf{N}$ & $\%$ & $\mathbf{N}$ & $\%$ & \\
\hline Systemic Arterial Hypertension $(n=2,244)$ & & & & & 0.108 \\
\hline Yes & 73 & 4.7 & 21 & 3.1 & \\
\hline Diabetes mellitus ( $n=2,231)$ & & & & & 0.255 \\
\hline Yes & 76 & 4.9 & 41 & 6.1 & \\
\hline Hypercholesterolemia $(n=2,222)$ & & & & & $0.013^{*}$ \\
\hline No & 1267 & 81.5 & 513 & 76.8 & \\
\hline Yes & 287 & 18.5 & 155 & 23.2 & \\
\hline
\end{tabular}

Person's Chi-square test - * $\mathrm{p} \leq 0.05$.

Table 2. Area under the ROC curve and $95 \% \mathrm{Cl}$ of time using the computer as a discriminator of obesity, sedentary lifestyle and cardiovascular risk factors in University students. Goiás, 2018.

\begin{tabular}{|c|c|c|c|c|}
\hline \multirow{2}{*}{ Variables } & \multicolumn{2}{|c|}{ Female } & \multicolumn{2}{|c|}{ Male } \\
\hline & AUC $(95 \% C l)$ & $p$-value & AUC $(95 \% C I)$ & p-value \\
\hline Obesity & $0.560(0.494-0.627)$ & 0.108 & $0.535(0.457-0.613)$ & 0.325 \\
\hline $\mathrm{SAH}$ & $0.574(0.506-0.643)$ & $0.032^{*}$ & $0.499(0.387-0.611)$ & 0.987 \\
\hline Diabetes & $0.509(0.445-0.572)$ & 0.794 & $0.534(0.436-0.632)$ & 0.487 \\
\hline
\end{tabular}

AUC $=$ Area under the curve; $\mathrm{ROC}=$ Receiver Operating Characteristic; $95 \% \mathrm{Cl}=95 \%$ confidence interval; $\mathrm{SAH}=$ systemic arterial hypertension; ${ }^{*} p<0.05$.

Graph 1. Area under the (ROC) curve with cutoff point for computer time as a discriminator of sedentary lifestyle in female university students in Goiás, Brazil, 2018.

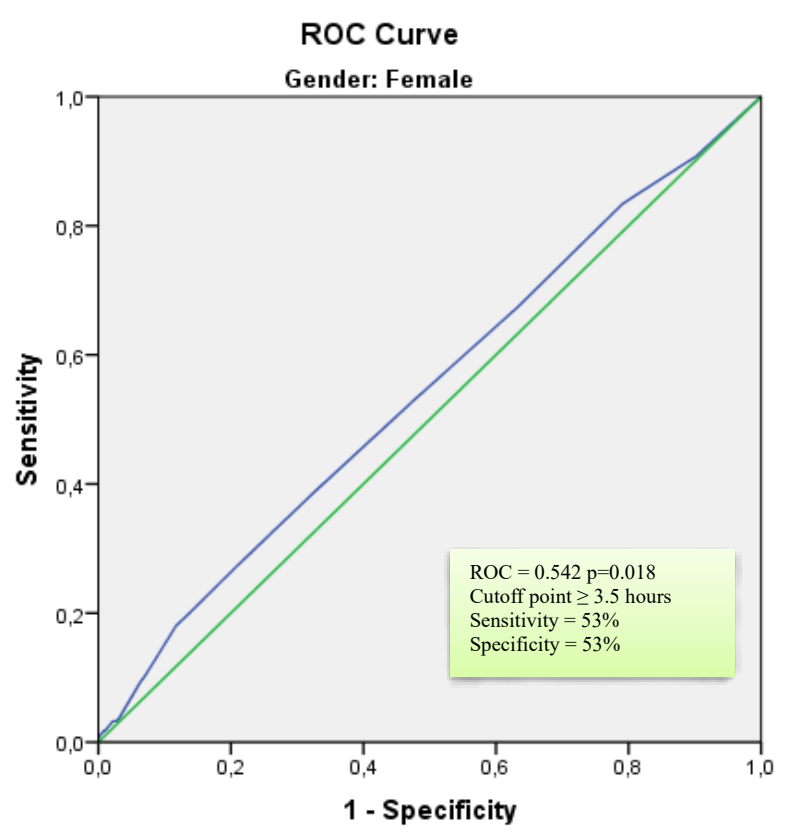

Graph 2. Area under the (ROC) curve with cutoff point for computer time as a discriminator of sedentary lifestyle in male university students in Goiás, Brazil, 2018.

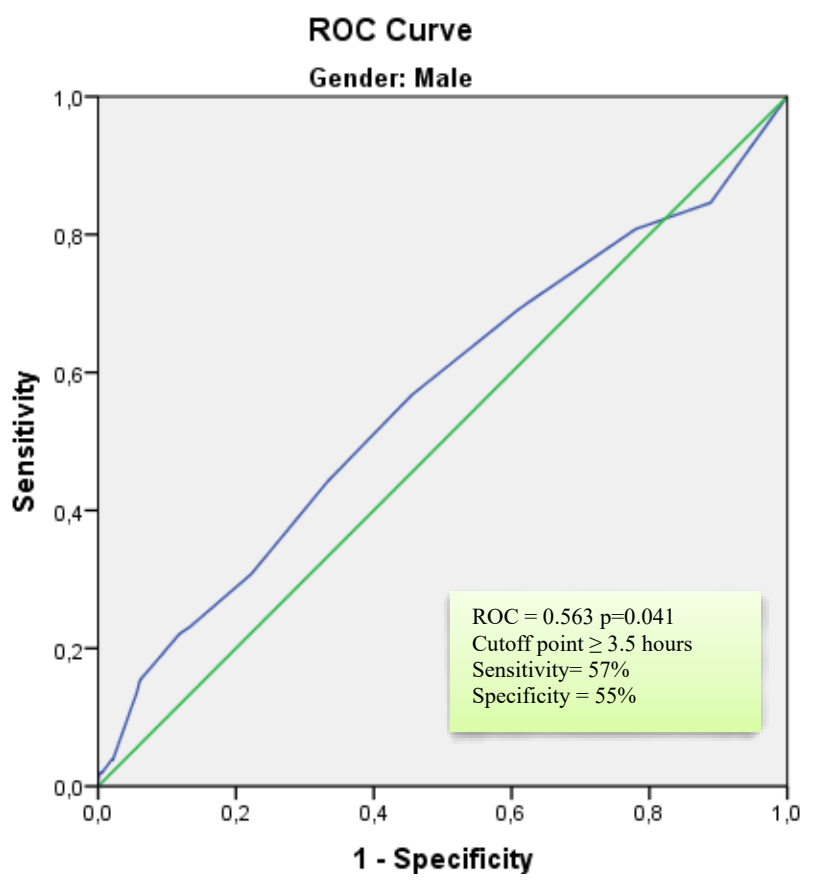


Graph 3. Area under the curve (ROC) with cutoff point for computer time as a discriminator of systemic arterial hypertension in female university students from Goiás, Brazil, 2018.

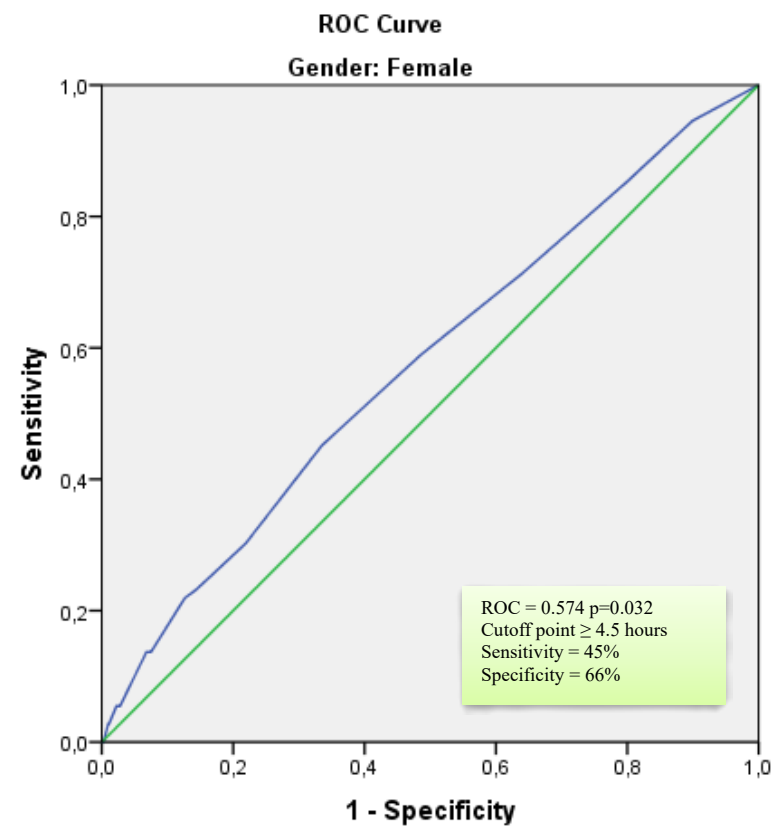

\section{DISCUSSION}

The present study sought to demonstrate the discriminatory power and cutoff point of time using the computer in relation to some conditions such as obesity, sedentary lifestyle and risk factors for cardiovascular disease in university students. Few studies in the literature have used sedentary behavior or one of its components as a discriminator of health conditions in the university population, as opposed to other groups such as children ${ }^{19}$, adolescents ${ }^{20}$ and the elderly ${ }^{21,22}$.

The analysis identified the values that showed the best balance between sensitivity and specificity to discriminate the presence of sedentary lifestyle and SAH among undergraduate students. The data showed that the TC predictive capacity to discriminate the presence of sedentary lifestyle was higher among men than women, as the AUC values for women were lower. For SAH, the TC showed discriminatory power among women, only.

The literature has shown differences regarding SB when comparing men and women because, depending on the considered domain, one gender could overlap the other. A study with data from eight Latin American countries showed that men had higher SB than women when using computers, playing video games, reading and during commuting, regardless of age ${ }^{15}$. However, in the present study, the average time using a computer among male and female university students was equivalent; perhaps because the activities performed daily that involved the use of this device were similar.
Regarding the cutoff points, it is important to emphasize that the literature does not yet have a consensus on the amount of time after which excessive sedentary behavior could be harmful to health, and it is possible to find time periods ranging from 2 hours to 10 hours or more per day ${ }^{23}$. A study that sought to observe the relationship between $\mathrm{SB}$, cardiovascular disease and mortality in adults found that 2 hours/day of screen time was associated with a $5 \%$ increase (HR 1.05; 95\% Cl 1.01-1.09) in cardiovascular events ${ }^{24}$.

Other studies carried out in Brazil tried to identify the most appropriate cutoff point for the university population. In the state of Minas Gerais, the authors sought to select the best cutoff points for sitting time as a discriminator of the absence of reported morbidities, such as obesity, overweight, SAH, high cholesterol and high blood glucose levels. They concluded that the best cutoff point for the absence of SAH was 6 hours $^{25}$. In the state of Bahia, a study with nursing students indicated that a sitting time of 8 hours or more per day was the one that best discriminated abdominal obesity among female students ${ }^{26}$. Therefore, these studies found cutoff points that were well above those shown in the analysis of the present study.

A systematic review of the literature on sedentary behavior showed that university students spent an average of 7.29 hours a day sitting, longer than the average of young adults in high-income countries. In this same review, the synthesis of data on the average time using the computer was $2.91(95 \% \mathrm{Cl} 2.32-3.5)$ hours per day, lower than the value found in the present study, both for men and women.

When considering the high possibility that the university students will work in future occupations where they will be exposed to long periods of sitting time during the workday, the data become a matter of concern, as the tendency for this sitting time is to increase. A study carried out with adults in the USA confirmed that sedentary time increased in the last decade in all analyzed subgroups, considering age, gender, level of schooling, skin color/ ethnicity and $\mathrm{BM}^{27}$.

The literature shows a negative association between sedentary behavior and physical activity ${ }^{3}$. Physically active university students tend to dedicate less time to sedentary behavior ${ }^{28}$. A sedentary lifestyle can cause several damages to health, such as, for instance, predisposing the individual to overweight and obesity, which in turn are related to other problems. Case-control studies with Bangladeshi university students showed that those who did not engage in any physical activity had a 3.2-fold greater chance of being obese or overweight when compared to physically active ones (OR= 3.2; $95 \% \mathrm{Cl}: 1.0-9.9 ; \mathrm{p}<0.05)^{29}$.

In the present study, although the stratified analysis did not show a great difference, both women and men spent almost 
a shift of their day in front of a computer, without considering the other SB components, which represented almost $25 \%$ of the time of wakefulness. This fact drew attention and became even more of a concern because, due to the global health situation caused by the Covid-19 pandemic, the routine of most people has changed, with a particular impact on the student sphere, with classes being taught remotely, requiring that students spend more time than usual in front of electronic devices, such as computers and smartphones.

An analysis with university students in Spain showed that sitting time increased during the lockdown period in all groups of evaluated students, reflecting the consequences brought by the restriction period due to the pandemic ${ }^{30}$. In Brazil, a survey that investigated several behaviors of the Brazilian population during the Covid-19 pandemic showed an increase in the average time spent watching TV and using a computer or tablet, with an increase of 1 hour and 30 minutes in relation to the time spent with these activities before the pandemic. The longest average time of computer use was seen among young adults aged 18 to 29 years, with approximately 7 hours and 15 minutes, representing an increase of almost 3 hours over the time of use before the pandemic ${ }^{31}$.

The strengths of this study comprise the representativeness of the sample of university students from a region of the country that is still little explored, the stringent study conduct, as well as the relevance of knowledge about a component of sedentary behavior that is very present in this population and its relationship with certain conditions in the health field. Furthermore, there are few studies that performed this type of analysis, especially in Brazil.

Among the limitations are the assessment of TC through a questionnaire and the use of self-reported measures to obtain information on morbidities. However, this type of measure has been frequent in epidemiological studies ${ }^{3,32}$. It is worth noting that the information was collected before the Covid-19 pandemic and that, due to the measures adopted to deal with the disease, the findings may have been modified for the worse. Another limitation is related to the cross-sectional study design, which requires caution when interpreting the findings, since longitudinal or experimental studies would be more adequate to demonstrate the relationship between TC and the presence of certain conditions.

\section{CONCLUSION}

It was concluded that the TC had a good capacity to discriminate the presence of sedentary lifestyle in university students and systemic arterial hypertension among female students. The cutoff points that best discriminated these conditions were 3.5 and 4.5 hours, respectively.
When reflecting on the findings, it is suggested that reducing $\mathrm{TC}$ and replacing it with active behaviors can contribute to improving the health profile and quality of life of university students, working as a preventive approach against cardiometabolic diseases and sedentary lifestyle. The data may suggest that future epidemiological studies on screen time in university students should pay more attention to the time using a computer.

\section{AUTHORS' CONTRIBUTION}

Heloísa Silva Guerra participated in the project design, data collection, analysis and interpretation of data, writing and critical review of the manuscript. Adriana Vieira Macedo Brugnoli and Raiana Rodrigues Costa Melo participated in data collection, data interpretation and critical review of the manuscript. Emílio Hideyuki Moriguchi: participated in data interpretation and critical review of the manuscript. Marcos Pascoal Pattussi participated in the project design, data interpretation and critical review of the manuscript. Juvenal Soares Dias da Costa participated in the project design, data analysis, interpretation and critical review of the manuscript.

\section{CONFLICTS OF INTEREST}

The authors declare no conflicts of interest.

\section{SOURCES OF FUNDING}

The authors declare no sources of funding.

\section{REFERENCES}

1. Rezende LFM, Lopes MR, Rey-López JP, Matsudo VKR, Luiz OC. Sedentary behavior and health outcomes: an overview of systematic reviews. PLoS ONE. 2014;9(8):e105620.

2. Vainsshelboim B, Brennan GM, LoRusso S, Fitzgerald P, Wisniewski KS. Sedentary behavior and physiological health determinants in male and female college students. Physiol Behav. 2019; 204:277-82.

3. Castro O, Bennie J, Vergeer I, Bosselut G, Biddle SJH. Correlates of sedentary behavior in university students: a systematic review. Prev Med. 2018;116:194-202.

4. Cotton $\mathrm{E}$, Prapavessis $\mathrm{H}$. Increasing nonsedentary behaviors in university students using text messages: randomized controlled trial. JMIR Mhealth Uhealth. 2016 Aug 19;4(3):e99.

5. Castro O, Bennie J, Vergeer I, Bosselut G, Biddle S. How sedentary are university students? A systematic review and meta-analysis. Prev Sci. 2020;21(3):332-43.

6. Crombie AP, Ilich JZ, Dutton GR, Panton LB, Abood DA. The freshman weight gain phenomenon revisited. Nutr Rev. 2009;67(2):83-94.

7. Vella-Zarb RA, Elgar FJ. The "freshman 5": a meta-analysis of weight gain in the freshman year of college. J Am Coll Health. 2009;58(2):161-6.

8. Williams J, Allen L, Wickramasinghe K, Mikkelsen B, Roberts N, Townsend $\mathrm{N}$. A systematic review of associations between non-communicable diseases and socioeconomic status within low-and lower - middle income countries. J Glob Health. 2018;8(2):1-25.

9. Lopes PD, Rezende AAA, Calábria LK. Fatores de risco para doenças crônicas não transmissíveis em universitários. Rev Bras Promoç Saúde. 2017;30(4):1-11 
10. Ribeiro AG, Cotta RMM, Ribeiro SMR. A promoção da saúde e a prevenção integrada dos fatores de risco para doenças cardiovasculares. Cien Saude Colet. 2012;17(1):7-17.

11. Brasil. Pesquisa Nacional de Saúde 2019: atenção primária à saúde e informações antropométricas. Rio de Janeiro: IBGE; 2020.

12. Associação Brasileira de Empresas de Pesquisa. Critério de Classificação Econômica Brasil. CCEB; 2016 [acesso em 10 nov 2020]. Disponível em: https://www.abep.org/criterio-brasil.

13. The IPAQ Group. Guidelines for Data Processing and Analysis of the International Physical Activity Questionnaire. 2005 [acesso em 18 jul 2021]. Disponível em: http://www.ipaq.ki.se.

14. World Health Organization. Obesity: preventing and managing the global epidemic. Report of a WHO consultation. WHO; 1998 [acesso em 18 jul 2021]. Disponível em: https://apps.who.int/iris/handle/10665/63854.

15. Ferrari LM, Werneck AO, Silva DR, Kovalskys I, Gómez G, Rigotti A, et al. Socio-demographic correlates of total and domain-specific sedentary behavior in Latin America: a population-based study. Int J Environ Res Public Health. 2020;17(5587):1-19.

16. Barros MBA, Lima MG, Medina LPB, Szwarcwald CL, Malta DC. Social inequalities in health behaviors among Brazilian adults: National Health Survey, 2013. Int J Equity Health. 2016;15:148-57.

17. Schisterman EF, Faraggi D, Reiser B, Trevisan M. Statistical inference for the area under the receiver operating characteristic curve in the presence of random measurement error. Am J Epidemiol. 2001;154(2):174-9.

18. Lasko TA, Bhagwat JG, Zou KH, Ohno-Machado L. The use of receiver operating characteristic curves in biomedical informatics. J Biomed Inform. 2005;38(5):404-15.

19. Oliveira LC, Ferrari GLM, Araújo TL, Matsudo V. Excesso de peso, obesidade, passos e atividade física de moderada a vigorosa em crianças. Rev Saude Publica. 2017;51(38):1-12.

20. Pitanga FJG, Alves CFA, Pamponet ML, Medina MG, Aquino R. Screen time as discriminator for overweight, obesity and abdominal obesity in adolescents. Rev Bras Cineantropom Desempenho Hum. 2016;18(5):539-47.

21. Silva PAS, Rocha SV, Vasconcelos LRC, Santos CA. Sedentary behavior as discriminator of common mental disorders in elderly. J Bras Psiquiatr. 2017;66(4):183-8.
22. Jesus AS, Rocha SV. Comportamento sedentário como critério discriminador do excesso de peso corporal em idosos. Rev Bras Ativ Fís Saúde. 2018;23:e0030.

23. Franco DC, Ferraz NL, Sousa TF. Sedentary behavior among university students: a systematic review. Rev Bras Cineantropom Desempenho Hum. 2019;21:e56485.

24. Ford ES, Caspersen CJ. Sedentary behaviour and cardiovascular disease: a review of prospective studies. Int J Epidemiol. 2012;41:1338-53.

25. Franco DC. Comportamento sedentário em universitários: estimativas de acurácia, prevalências e fatores associados [dissertação]. Uberaba: Universidade Federal do Triângulo Mineiro; 2019.

26. Mussi FC, Pitanga FJG, Pires CGS. Cumulative sitting time as discriminator of overweight, obesity, abdominal obesity and lipid disorders in nursing university. Rev Bras Cineantropom Desempenho Hum. 2017;19(1):40-9.

27. Du Y, Liu B, Sun Y, Snetselaar LG, Wallace RB, Bao W. Trends in adherence to the physical activity guidelines for Americans for aerobic activity and time spent on sedentary behavior among US adults, 2007 to 2016. JAMA Netw Open. 2019;2(7):e197597.

28. Carballo-Fazanes A, Rico-Díaz J, Barcala-Furelos R, Rey E, RodríguezFernández JE, Varela-Casal C, et al. Physical activity habits and determinants, sedentary behaviour and lifestyle in university students. Int $J$ Environ Res Public Health. 2020;17(9):1-15

29. Banna HA, Brazendale K, Hasan M, Khan SI, Sayeed A, Kundu S. Factors associated with overweight and obesity among Bangladeshi university students: a case-control study. J Am Coll Health. 2020;1:1-7.

30. Romero-Blanco A, Rodríguez-Almagro J, Onieva-Zafra MD, ParraFernández ML, Prado-Laguna MC, Hernández-Martínez A. Physical activity and sedentary lifestyle in university students: changes during confinement due to the Covid-19 pandemic. Int J Environ Res Public Health. 2020;17(6567):1-13.

31. Malta DC, Szwarcwald CL, Barros MBA, Gomes CS, Machado IE, Souza Júnior PRB, et al. A pandemia da Covid-19 e as mudanças no estilo de vida dos brasileiros adultos: um estudo transversal, 2020. Epidemiol Serv Saude. 2020;29(4):e20200407.

32. Moreira JPL, Almeida RMVR, Rocha NCS, Luiz RR. Correção da prevalência autorreferida em estudos epidemiológicos com grandes amostras. Cad. Saude Publica. 2016;32(12):e00050816. 